\title{
The model of local e-administration development
}

\author{
Agnieszka Agata Tomaszewicz \\ University of Szczecin \\ Faculty of Management and \\ Economics of Services \\ ul. Cukrowa 4, 71-004 Szczecin Poland \\ Email:agnieszka.tomaszewicz@wzieu.pl
}

\begin{abstract}
ICT which constitutes basis for e-administration development, is used more and more often in office-citizen kind of communication. Thus, terms regarding the state and directions of local e-administration development are quite often discussed in polish literature. However, they are seldom held on the local level i.e. local authorities. The issues regarding improvement of service among local communities resulting from applying e-administration solutions are particularly researched. Hence, the article presents the results of enhanced scientific research in the area of impact of local e-administration solutions on service efficiency among citizens which result in proposal of the model of local e-administration development. Its' application shall enable proper usage of local e-administration potential as well as improving service for local communities.
\end{abstract}

\section{INTRODUCTION}

I $\mathrm{N}$ TODAY'S economy, the Internet plays an important role as a mean of communication and distribution and as such it shall be used intensively by local units in order to improve the service for their communities. The Internet shall be used by offices to improve the whole process of providing services so that it would result in implementation of full offer of e-services available on the offices' web pages. Providing dynamic development of e-administration and wide usage of provided services via electronic channels shall result in better, more efficient and effective functioning of local offices. It will foster both, more efficient customers service and implementing new computerised solutions enabling growing customers' needs and even stay ahead of them. Thus, it may be assumed that e-administration is public administration in which the use of information and communication technologies (ICT) contributes to better administrational service for citizens thereby improving the quality of their life. On the basis of the needs and improvements identified in the research, which result from the implementation of e-administration in municipalities of West Pomeranian Voivodeship, it was concluded that self-governmental administration has the potential which may contribute to improvement of services for local communities. The development of public e-services, particularly at the initial stage of development, depends on the access and the quality of public e-services which specify the advance level of their development. Therefore, in order to increase the access to public e-services in municipalities, the growth of their maturity and improvement of customer service, resulting in better quality of life regarding citizens and better quality of realized business processes regarding entrepreneurs, the model of local e-administration development was created on basis of research held in municipalities of West Pomeranian Voivodeship. The municipalities do not vary from the whole population regarding the researched qualities.

\section{LiteratURE REVIEW}

The innovative approach towards improvement of governmental effectiveness, according to M.A. Abramson, J.D, Breul, J. M. Kamensky, is driven by the technological development which lead to vital changes in functioning of organizations both, in public and private sector contributing to improvement of administration efficiency. They claim that technology shall be seen not only as a basic activity of public administration but as a driving force for its activity [1]. The biggest advantage of that kind of innovation is to create grounds to change the nature of business and interpersonal communication and to establish new relationships between people and organizations [2]. According to H. Izdebski [3], progress connected with the technical development of IT facilitates contact with offices by obtaining desired information or settling the matter via electronic way. Thanks to the development and better access to the technologies, the meaning of electronic administration shall be systematically growing [4]. The influence of the administration on the economy, particularly by using ICT in recent years is seen as a factor which boosts economy and leads to public sector transformation, drastically changing the way of functioning of public institutions [5]. Within the research conducted for the needs of eGovernment Readiness Index, five e-administration models were found [6]: 
1. centralized- where the information and public services system is organized around the main national portal and presented information are highly unified;

2. decentralized- based on the individual sites, created separately for particular institutions, initiatives and programs in which collective public platforms play only referential function and presented information are not standardized;

3. network- in which systemic character is obtained by the number and kind of links between particular websites;

4. e-participation oriented- in which the base constitute the tools enabling citizens' engagement in creating the administrational processes and making decisions;

5. e-services oriented- in which computerization of the processes like back-office and front-office are treated as the most important factor in creating e-administration systems.

The approach to local administration keeps on evolving all the time. Currently, it is expected that it shall implement citizens' participation in the process of creating public services. Additionally, in places where it has not been implemented yet, administration shall pass from top-down hierarchical effectiveness to bottom-up, meaning democratic one. This effectiveness is measured on the basis of the results and in the given context. As far as changes in new administration paradigm are considered, in e-administration focus on the client shall prevail.

\section{RESEARCH METHODOLOGY}

\section{A. Population of the study}

The subject and the main area of the research were local authorities in West Pomeranian Voivodeship (urban, including city with powiat rights, urban-rural and rural) and local communities which are serviced by these authorities. The research includes the subjects: (1) Local authorities in West Pomeranian Voivodeship in which research was conducted on three stages: (Stage I) - online survey regarding the state of local e-administration; (Stage II) - the analysis of the websites of municipalities chosen from stage I of the research; (Stage III) - direct interview with the representatives of the local authorities; (2) Local communities of the West Pomeranian Voivodeship which were included in the survey.

\section{B. Data collection}

The model was elaborated on the basis of the used secondary and primary information sources by using the following research methods: CAWI technique (Computer Assisted Web Interviews), survey technique, was used among local communities which was drawn on the basis of random sample; direct interview, applied in order to identify problems connected with the development of local administration; critical analysis method- including observation of the websites' content method and applying e-administration solutions in municipalities in West Pomeranian Voivodeship; analysis method of the service provided for the local communities by local authorities in order to identify needs and expectancies within the scope of e-administration; Case
Study Method-presenting particular solutions connected with local e-administration.

The data collected from the primary and secondary sourced was used to create the model of improving local eadministration.

\section{Reliability and validity}

The questionnaire that was used in the present study was rigorously tested for its content and construction validity. A draft of the final questionnaire was shown to two officials and three academics, in order to test whether it met all theoretical and practical requirements.

The research conducted at the second stage regarded mainly functioning of the websites on the task level. The subject of the research were local e-services. The content of the offices' websites was not analyzed multidimensionally but it focused merely on the basic terms within the scope of adjusting the websites to providing services for local communities.

\section{CONCEPTUAL FRAMEWORK}

The basic approach in the proposed model is process approach. Implementing the model which enables meeting the requirements of the local communities, requires its' constant adjustment to changing citizens' and environment's needs. The model was graphically presented in the Figure 1 .

\section{A. Modules of local e-administration}

In the structure of the model aiming at creating coherent work of local e-administration, it was necessary to identify particular stages designed to improve the service for local communities by local authorities units. The model includes five basic modules which constitute the core of local eadministration (e-A). They include: (1) inventory of the customers service processes in the local offices, (2) recognizing the needs of local customers (citizens, entrepreneurs, other public institutions), (3) the standardization and improvement of processes and public services (in the traditional and electronic meaning), (4) interoperability of the processes and implemented/developed e-services by development and closer cooperation of the units engaged in the process of providing e-services, (5) digitalization of the public services/ the increase in maturity of the available public e-services. In order to specify the level of citizens' satisfaction, offices may use monitoring. Due to changeable character of local communities' needs, the process of monitoring must be in compliance with the rule of continuous improvement by Deming [7]: constant checking whether implemented solutions still respond to citizens' preferences. This activity will not require financial or material outlays. Specifying the needs and preferences of the final customer of local e-administration influences the increase in adaptability of the proposed model.

Bearing in mind, that the customers' needs are tightly connected with the realization of public services, it is legitimate that the accepted model is targeted at creating new 


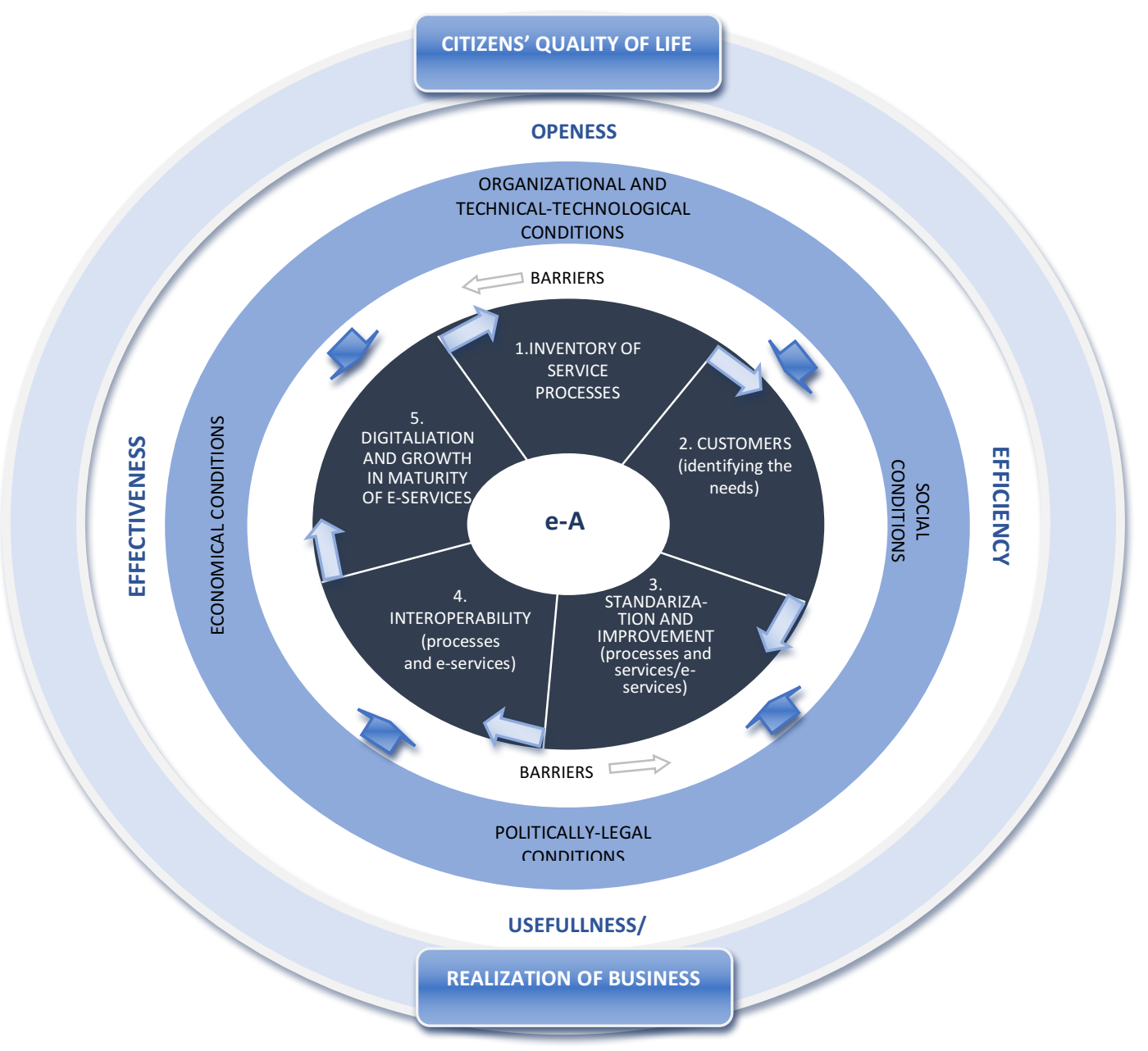

Fig.1 The model of improving local e-administration (e-A) Source: own elaboration

services and expanding maturity of the existing e-services which main objective is to be adjusted to the local communities' needs. Digitalization constitutes the basic tool in creating social models, including local administration units which shall broadly use its potential, particularly in stimulating social development.

\section{B. Barriers in e-administration development}

Implementing the model ay encounter numerous obstacles which may include; organizational barriers, legal, economic, political, technological or social. They may occur on different staged and levels and ay influence slowing the whole process down. One of the most prominent limits are lack of interoperability, lack of unified standards on municipalities' websites, customers' low knowledge on ICT use, necessity of autonomous search of information while handling the matters on the Internet or too complicated service implementation process via the Internet. The access to ICT technology or the willingness to handle the official matters online are believed to be the most crucial obstacles. The obstacle in implementing e-administration in municipalities may be unclear or the websites be not functional. In order to remove this barrier, it is particularly necessary for offices to share services via one website especially designed for it. Currently, councils use even 4 websites (council's own website, BIP, eBOI and ePUAP) having discretion in posting e-services on them. The key barrier which often is finally associated with responsibility for success in e-administration implementation is the cost barrier. EU funds are particularly helpful in this area. From the implementation of the model point of view, particularly important stage is identification and fast elimination of the existing barriers or their removal. These activities shall be consequences of continuous improvement of the e-administration process in communal authority units.

\section{Conditions for e-administration development}

The success of realizing the model for e-administration development depends on the understanding and knowing the external conditions which may influence it. These conditions may enable it to reach the highest stage of public e-services development, thus, constituting administrational offer for the users. Conditions which are particularly emphasized, include 
technically-technological, economic, politically-legal, social and organizational conditions. Besides presenting determinants specified in the model of e-administration development one shall also refer to the theory of critical success factors. In Poland the most important critical success factors (CSFs) of e-administration, as well noticed by E. Ziemba and T. Papaj, are these which are connected with finances, integration and interoperability of public e-services with various systems of public administration institutions, employees' IT skills and top-level management engagement, information safety or implementing innovative teleinformatic infrastructure in public institution, availability of free software [8],[9],[10].

\section{EMPIRICAl Results}

The results of the conducted research enable formulating the following detailed conclusions: 1. E-administration improves communication between citizens and councils. Along with the development of the Internet, this form of communication will be more popularized and intensified. 2. Municipalities of West Pomeranian Voivodeship are characterized with low level of local e-administration development. 3 . Low level of local e-services maturity influences rather poor citizens' interest in handling matters with the use of the Internet. In West Pomeranian Voivodeship amounts to $47 \%$ (including only $69 \%$ of citizens who only download the electronic forms from the websites). However, the vast majority of the participants, up to $74 \%$, feel the need to fully manage at least one out of 12 basic official issues. 4 . The increase in advance level of public e-services development and functionality of the websites shall contribute to better service provided for local communities. 5. Higher percentage of citizens who used the Internet while dealing with official matters, claim that it had a positive effect on the quality of the services provided than these people who claimed that there was no improvement. 6 . The level of adjusting the websites and their functionality are varied and it is hard to evaluate them clearly. However, mostly customers due to council's use of few internet portals, encounter obstacles in finding the matter they are interested in because it may be provided on different websites. 7. A meaningful problem remains; the lack of coherence and standardization of documents. Local authorities shall establish cooperation with other units, particularly on local level. 8. The factor conditioning wider scope, form and intensity of public e-services use is obtaining proper digital skills both, by employees and customers. IT courses may seem helpful in this area.

\section{Conclusions}

The local e-administration has potential to enable, in a considerable manner, contributing to improved service pro- vided for local communities. In conclusion, essential factors which condition the success of implementing the model of local e-administration are as following: 1 . Noticing the need for changes by local authorities and their engagement in the process of implementing solutions within the scope of local e-administration on every stage. 2. Accepting efficiency, effectiveness, openness and usability as basic results' measures of implementing the model of e-administration development. 3. Implementing standardization and interoperability as basic factors responsible of work efficiency. 4. Reliable valuation of the project costs and guarantee in financing it. 5. Obtaining proper IT skills by employees and social communities. 6. Using the teleinformatic technology. 7. Participation of local communities and their approval for new tools implemented in municipal administration. 8. Coordination, cooperation, monitoring and evaluation. 9. Constant adjustment to changing needs of the environment.

The benefits of implementing the model of local e-administration are connected with improved skill of satisfying the needs of local communities as a result of the maturity growth (improving the quality of services) or sharing new public e-services.

\section{REFERENCES}

[1] M. A. Abramson, J. D. Breul, J M. Kamensky, Report "Six Trends Transforming Government", IBM Center for the Business of Government, Washington 2006, p. 4.

[2] A. Budziewicz-Guźlecka, Management of changes in enterprises as a form of adaptation to e-economy, Scientific Journal No. 681 Service Management Vol. 8, Szczecin 2012, p.202

[3] H. Izdebski, Samorzad Terytorialny. Podstawy Ustroju i Działalności, Edition II, Wydawnictwo Prawnicze Lexisnexis Sp. z o.o., Warszawa 2003, p. 47.

[4] P. Minkowski, P. Motek, R. Pedał, Poziom zaawansowania wielkopolskich urzędów gmin $w$ zakresie informatyzacji $i$ rozwoju elektronicznych ustug publicznych, Wydawnictwo M-Druk, Poznań 2009 , p. 8.

[5] M. Kowalczyk, E-Urzad w komunikacji z obywatelem, Wydawnictwa Akademickie i Profesjonalne, Warszawa 2009, p.7.

[6] G. Curtin, Global E-Government/E-Participation Models, Measurement And Methodology: A Framework For Moving Forward, Unipan, New York 2006, p. 21-24, http://unpan1.un.org/intradoc/ groups/public/documents/un/unpan023680.pdf.

[7] The Deming Cycle (or Deming Wheel), is referred to as the PDCA Cycle (Plan-Do-Check-Act), is the W.E concept. Deming, containing chronologically ordered actions aimed at continuous improvement. it takes place in the cycle: planning - execution - checking - operation. (http://quality-managemnet.pl/pdca/70-14-zasad-filozofiideminga.html).

[8] E. Ziemba, T. Papaj, Determinanty I Bariery Rozwoju E-Administracji $W$ Polsce, conference materials, http://www.dabrowa-gornicza.pl/ portal/download/file_id/29123/pid/1763.html

[9] S. Assar, I. Boughzala, I. Boydens, Practical studies in e-Government. Best Practices from Around The World, Springer, 2011, p.1.

[10] L. Alzahrani, W. Al-Karaghouli, V. Weerakkody, Analysing the critical factors influencing trust in e-government adoption from citizens' perspective: A systematic review and a conceptual framework, International Businnes Review, Volume 26, Issue 1, 2017, p. 70-71; https://doi.org/10.1016/j.ibusrev.2016.06.004. 